\title{
The In Vivo Time Course for Elimination of Adrenalectomy-Induced Apoptotic Profiles from the Granule Cell Layer of the Rat Hippocampus
}

\author{
Zhongting Hu, Kazunari Yuri, Hitoshi Ozawa, Haiping Lu, and Mitsuhiro Kawata \\ Department of Anatomy and Neurobiology, Kyoto Prefectural University of Medicine, Kawaramachi-Hirokoji, Kamigyo-ku, \\ Kyoto 602, Japan
}

\begin{abstract}
Although apoptotic cellular degeneration has been reported to be extremely rapid with the use of in vitro models, the time needed to clear apoptotic neurons in the in vivo brain is unknown. In this study we used a simple morphological approach to solve this problem. Four days after adrenalectomy (ADX), all of the operated rats morphologically displayed hippocampal granule cell apoptosis that was prevented completely by corticosterone replacement immediately after ADX. Therefore, we intravenously injected the rats with corticosterone $4 \mathrm{~d}$ after ADX and subsequently maintained them on corticosterone replacement in saline drinking water. This corticosterone replacement could protect healthy granule cells promptly and continuously against hormone-deficient apoptosis, because the normal glucocorticoid receptor immunoreactivity within the granule cell nuclei, which disappeared after ADX, was identified $1 \mathrm{hr}$ after corticosterone replacement was started, and this effect persisted for several days. However, this corticosterone treatment
\end{abstract}

could not prevent the irreversible apoptosis of the already degenerated granule cells at various stages of the same progressive apoptotic process. Then we successively traced the disappearance of apoptotic granule cells throughout the hippocampus at different time points by Nissl and silver staining. Given that the apoptotic cells at the earliest stage of the degenerating process when the ADX rats received corticosterone injection were the last to disappear, the period from corticosterone injection until the disappearance of the last degenerating debris of apoptotic cells was taken to represent the time course for elimination of apoptotic neurons in vivo. We discovered that the elimination of apoptotic granule cells took $72 \mathrm{hr}$.

Key words: adrenalectomy; corticosterone; granule cell; apoptosis; silver and Niss/ staining; chromatin condensation; time course
Cell death is a common phenomenon that plays an important role in the control of the morphology and size of forming tissues and organs (Wyllie, 1981; Ucker, 1991). Since the emergence of the concept of apoptosis (Kerr et al., 1972), numerous studies have focused on this research field. Under light and electron microscope, the typical morphological changes of apoptotic cells take place in the following sequence: clumping of chromatin against the nuclear membrane, condensation of the nucleus and cytoplasm, breaking up of pyknotic cells into apoptotic fragments, and digestion of apoptotic bodies (Kerr et al., 1972; Clarke, 1990; Sloviter et al., 1993b). The different morphological profiles of apoptotic cells are thought to reflect diverse stages of cell degeneration (Kerr et al., 1972; Sloviter et al., 1993a,b). Although several hypotheses have been proposed to explain the complicated mechanism of apoptosis (Vaux, 1993), there is unanimous agreement that the apoptotic cells are eliminated within a few minutes (Russell et al., 1972; Sanderson, 1976; Matter, 1979; Kerr et al., 1987) and that apoptotic bodies of diverse forms are observed only within a period of several hours (Wyllie et al., 1980; Busch et al., 1990). However, all of the findings as to the exact time course

Received Dec. 19, 1996; revised Feb. 18, 1997; accepted March 10, 1997.

This research was supported by grants from the Ministry of Education, Culture, and Science of the Japanese Government to M.K. and by Sasagawa Research Foundation to Z.H. We thank Dr. M. Murakami for his invaluable help throughout the course of this study.

Correspondence should be addressed to Dr. Zhongting Hu, Department of Anatomy and Neurobiology, Kyoto Prefectural University of Medicine, KawaramachiHirokoji, Kamigyo-ku, Kyoto 602, Japan.

Copyright (C) 1997 Society for Neuroscience $0270-6474 / 97 / 173981-09 \$ 05.00 / 0$ of apoptotic cell degeneration were obtained from in vitro experiments (Sanderson, 1976).

It is not known how long it takes for apoptotic cells to undergo degeneration in vivo. Especially in the in vivo brain, no morphological evidence has been presented to demonstrate the time course of the lysis of apoptotic neurons. Sloviter et al. (1989) discovered that the adrenalectomy-induced loss of endogenous glucocorticoids, the hormones secreted from the adrenal glands, resulted in selective cell degeneration within the granule cell layer of the hippocampus, and this result has been replicated in subsequent experiments (Gould et al., 1990; Jaarsma et al., 1992; Sapolsky et al., 1991; Sloviter et al., 1993a). Shortly after adrenalectomy (ADX), $\sim 90 \%$ of the operated rats exhibited degeneration of the hippocampal granule cells (Jaarsma et al., 1992; Sloviter et al., 1993a). Morphological analysis demonstrated that the ADX-induced granule cell death was apoptotic (Sloviter et al., 1993a,b). The ADX-induced granule cell apoptosis was prevented completely by supplying the ADX rats with saline drinking water containing corticosterone at the dose of $20 \mu \mathrm{g} / \mathrm{ml}$ solution (Sloviter et al., 1989, 1993a). On the basis of the postulate that cellular apoptosis is irreversible once it has been triggered (Kerr et al., 1972) and that the apoptotic cells at the earliest stage of cell degeneration are the last to disappear, we quickly gave hormonedeficient rats, beginning $4 \mathrm{~d}$ after ADX, corticosterone replacement, which immediately prevented the apoptosis of healthy granule cells but not that of the already degenerated granule cells. We then successively traced the morphological disappearance of apoptotic granule cells. We discovered that the degenerating granule 
cells had not disappeared until $72 \mathrm{hr}$ after the administration of corticosterone was started in the ADX rats.

\section{MATERIALS AND METHODS}

\section{Animal treatment}

All of the rats used in this study were treated in accordance with the guidelines issued by the US National Institutes of Health for the humane treatment of experimental animals. The rats were divided into the following groups:

ADX of young rats induces hippocampal granule cell apoptosis. This experiment was designed to elucidate the distribution and the morphological profiles of apoptotic granule cells after ADX. Twenty male Sprague Dawley rats, 100 gm body weight (BW), were adrenalectomized bilaterally under aseptic procedure with ketamine anesthesia. Twelve other rats underwent sham operation as controls. Both the ADX and control groups were provided with $0.9 \% \mathrm{NaCl}$ in drinking water throughout the experimental course. For the examination of the appearance of apoptotic granule cells, five ADX and three sham-operated rats were killed at $1,2,3$, and $4 \mathrm{~d}$ after operation.

Corticosterone replacement blocks $A D X$-induced granule cell apoptosis. This experiment was designed to examine whether corticosterone replacement in this study could prevent the hippocampal granule cell apoptosis after ADX. Immediately after the ADX and sham operation as described above, corticosterone (Sigma, St. Louis, MO) dissolved in saline solution at $30 \mu \mathrm{g} / \mathrm{ml}$ was supplied to $20 \mathrm{ADX}$ and 12 shamoperated rats. Previous studies (Sloviter et al., 1989; Gould et al., 1990) demonstrated that $20-25 \mu \mathrm{g} / \mathrm{ml}$ corticosterone in saline drinking water increased the circulating level of corticosterone in ADX rats to the lower normal range and prevented granule cell death after ADX. To ensure the effect of corticosterone in protecting hippocampal granule cells from hormone-deficient apoptosis, we used the slightly excess dose of $30 \mu \mathrm{g} / \mathrm{ml}$. Five ADX and three sham-operated rats were perfused at each of 1,2,3, and $4 \mathrm{~d}$ after operation. The volume of corticosterone consumed by each ADX and sham-operated rat was recorded carefully every day.

The time course of the lysis of apoptotic granule cells. Thirty male Sprague Dawley rats (100 gm BW) were adrenalectomized bilaterally and provided with $0.9 \% \mathrm{NaCl}$ in drinking water immediately after operation. Twelve sham-operated rats were used as controls. Four days after operation, all of the rats in both groups received intravenous injection of corticosterone (1.5 mg in aseptic saline) and then were maintained on corticosterone replacement (corticosterone in saline drinking water at 30 $\mu \mathrm{g} / \mathrm{ml}$ ) for the durations indicated below. We chose to start the corticosterone replacement at $4 \mathrm{~d}$ after $\mathrm{ADX}$, because this was reported to be an adequate time frame to allow degeneration of numerous cells within the granule cell layer of the adult dentate gyrus (Jaarsma et al., 1992; Sloviter et al., 1993a,b) and because in our preliminary experiments we confirmed that all rats exhibited granule cell degeneration with variable morphological profiles within the dentate gyrus at $4 \mathrm{~d}$ after ADX. The dose of 1.5 $\mathrm{mg}$ of injected corticosterone was decided after we calculated the daily volume of corticosterone water consumed by each ADX rat. In the above experiment we observed the ADX rats daily and noted that each ADX rat drank a volume of $30-50 \mathrm{ml}$ of corticosterone saline water daily; $30-50$ $\mathrm{ml}$ of $30 \mu \mathrm{g} / \mathrm{ml}$ corticosterone solution contained $0.9-1.5 \mathrm{mg}$ corticosterone. ADX rats that received corticosterone replacement at this volume daily $(0.9-1.5 \mathrm{mg})$ did not exhibit any degenerating granule cells, suggesting that the corticosterone at this injected volume $(1.5 \mathrm{mg})$ could be distributed quickly into all of the hormone-deficient cells and could rapidly protect the healthy granule cells against hormone-deficient apoptosis. The volume of corticosterone/saline drinking solution consumed by each ADX or sham-operated rat also was recorded every day. At each of $1,4,12,24,48$, and $72 \mathrm{hr}$ after the start of corticosterone replacement, five ADX and two sham-operated rats were killed. To exclude the possibility that corticosterone treatment in our experiment induced possible stress or neurotoxic effects on the rats (Sapolsky, 1985), we weighed all of the rats before perfusion.

\section{Tissue preparation}

All of the rats in both the sham-operated and ADX groups were anesthetized deeply with ketamine and perfused with $100 \mathrm{ml}$ of $0.9 \% \mathrm{NaCl}$, followed by $500 \mathrm{ml}$ of $4.0 \%$ paraformaldehyde in $0.1 \mathrm{M}$ PBS with $2 \%(\mathrm{v} / \mathrm{v})$ picric acid. The brain was dissected out from the skull and post-fixed overnight in the same perfusion solution. Then the brains were immersed in $25 \%$ sucrose in $0.1 \mathrm{~m}$ PBS for $2 \mathrm{~d}$. Brain sections at different thicknesses were cut for different staining methods. For Nissl staining, $25-\mu \mathrm{m}$ - thick sections were mounted directly onto gelatin-coated glass slides and air-dried. The slides were stained with $1.0 \%$ cresyl violet, dehydrated, and coverslipped with Entellan. For silver degeneration and immunohistochemical staining, 50- $\mu \mathrm{m}$-thick sections were cut and collected in 0.1 м PBS.

\section{Silver impregnation stain}

The silver impregnation procedure described by Gallyas et al. (1980) was used to identify the degenerating granule cells, with our modification to obtain low background staining of the sections. In this staining procedure the sections were washed first with distilled water four times for $5 \mathrm{~min}$ each. Then they were immersed in the pretreating solution (containing a $1: 1$ solution of $9 \% \mathrm{NaOH}$ and $1.2 \%$ ammonium nitrate) for $10 \mathrm{~min}$, followed by $15 \mathrm{~min}$ in the impregnation solution $(18 \mathrm{ml}$ of $9 \% \mathrm{NaOH}$, $12-14 \mathrm{ml}$ of $16 \%$ ammonium nitrate, and $125-135 \mu \mathrm{l}$ of $50 \% \mathrm{AgNO}_{3}$ ). The sections were washed quickly (within $1 \mathrm{~min}$ ) but vigorously twice with a solution containing $100 \mu \mathrm{l}$ of $16 \%$ ammonium nitrate, $100 \mathrm{ml}$ of $5 \%$ $\mathrm{Na}_{2} \mathrm{CO}_{3}, 300 \mathrm{ml}$ of $95 \%$ ethanol, and $700 \mathrm{ml}$ of distilled water. Finally, the sections were immersed in developing solution (300-350 $\mu \mathrm{l}$ of $16 \%$ ammonium nitrate, $15 \mathrm{ml}$ of $37 \%$ formalin, $100 \mathrm{ml}$ of $95 \%$ ethanol, $100 \mathrm{ml}$ of $0.5 \%$ citric acid, and $285 \mathrm{ml}$ of distilled water) for $\sim 1 \mathrm{~min}$ or more. They were washed with $0.5 \%$ acetic acid for $30 \mathrm{sec}$ to stop the developmental reaction, then with distilled water, and last with $0.1 \mathrm{M}$ PBS for 5 min each. The sections were incubated with $5 \% \mathrm{~K}_{2} \mathrm{Cr}_{2} \mathrm{O}_{7}$ to reduce the nonspecific background staining. The sections again were washed with distilled water, followed by $0.1 \mathrm{M}$ PBS, and mounted directly on glass slides, air-dried, dehydrated in a graded alcohol series, cleared, and coverslipped.

\section{Immunohistochemical staining for glucocorticoid receptors}

Hippocampal sections from all of the ADX and control rats were subjected to immunohistochemical staining for examining the glucocorticoid receptor immunoreactivity (GR-IR) in the granule cell layer of the dentate gyrus. Sections were incubated first in $2 \% \mathrm{H}_{2} \mathrm{O}_{2}$ and in $2 \%$ normal goat serum for $60 \mathrm{~min}$ each and then immersed in primary antibodies (rabbit anti-GR serum at a dilution of 1:5000; Morimoto et al., 1996) for $3 \mathrm{~d}$ at $4^{\circ} \mathrm{C}$. After several washes the sections were incubated in biotinylated anti-rabbit IgG for $2 \mathrm{hr}$ (working dilution 1:1000; Boehringer Mannheim Biochemica, Mannheim, Germany) and then, after several more washes, in streptoavidin-peroxidase conjugate (dilution 1:4000; Boehringer Mannheim) for $2 \mathrm{hr}$ at room temperature. The reaction complex on the sections was visualized in a solution of $0.05 \% 3,3^{\prime}$ diaminobenzidine (DAB; Dojin, Kumamoto, Japan) and $0.01 \% \mathrm{H}_{2} \mathrm{O}_{2}$ for $15 \mathrm{~min}$. Sections were mounted on glass slides, air-dried, dehydrated, and coverslipped. For the evaluation of the specificity of our first antibody, several sections from control rats were incubated with normal rabbit serum (diluted 1:500-1000) instead of primary antiserum. No positive immunoreactive neurons were identified within the hippocampal granule cell layer or other brain structures.

\section{Statistical analysis}

Nissl-stained hippocampal sections from the rats adrenalectomized for $4 \mathrm{~d}$ and the ADX rats at $1,4,12,24,48$, and $72 \mathrm{hr}$ after corticosterone replacement were used for quantitative analysis. The sections selected for quantitative analysis were $\sim 100 \mu \mathrm{m}$ apart to avoid the necessity of correcting for twice-counted cells. The number of apoptotic granule cells with different morphological profiles (see Results, Morphological Analysis of Apoptotic Granule Cells) was recorded within the unilateral dentate gyrus. The means of numbers of apoptotic granule cells with different morphological profiles and the total numbers of apoptotic granule cells per section were calculated. Statistical significance was determined with Student's unpaired $t$ test, and the differences in the means from the $\mathrm{ADX}$ rats with corticosterone replacement $(n=5$ at each of six time points) and the rats adrenalectomized for $4 \mathrm{~d}(n=5)$ were established at $p<0.05$.

\section{RESULTS}

\section{Adrenalectomy-induced granule cell apoptosis}

ADX of young adult rats induced obvious cell degeneration within the granule cell layer of the dentate gyrus shortly after operation. We did not observe degenerating granule cells $1 \mathrm{~d}$ after ADX in Nissl- and silver-stained sections. The degeneration of hippocampal granule cells was observed first, in three of five operated rats, 


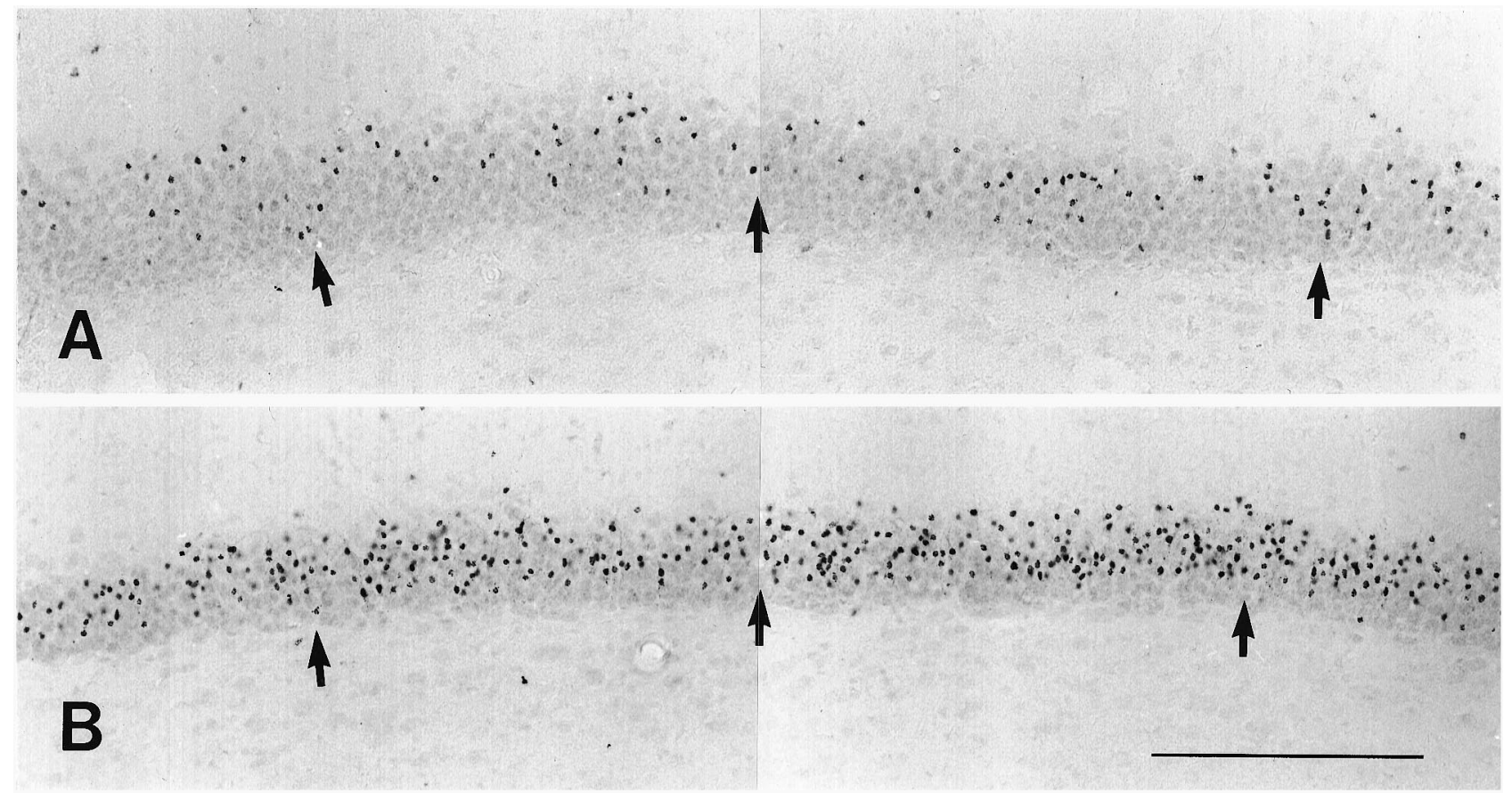

Figure 1. Silver-stained sections reveal degenerating cells within the suprapyramidal blade of the granule cell layer $4 \mathrm{~d}$ after ADX. Numerous silver-impregnated granule cells are seen after ADX. Different ADX rats exhibited varied numbers of the silver-stained granule cells (arrows in $A, B$ ). Scale bar, $200 \mu \mathrm{m}$ (for $A, B$ ).

$2 \mathrm{~d}$ after ADX. Three days after operation, $\sim 80 \%$ of the ADX rats exhibited cell degeneration in the granule cell layer. All of the ADX rats exhibited degenerating granule cells within the dentate gyrus $4 \mathrm{~d}$ after operation (Fig. 1). No obvious degenerating cells were found in the hippocampal granule cell layer of the shamoperated rats at any of the time points. Individual ADX rats exhibited greatly variable numbers of degenerating granule cells (Fig. $1 A, B$ ). The greatest number of degenerating granule cells usually was located in the lateral aspect of the suprapyramidal blade within the granule cell layer. We thus chose the suprapyramidal blade of the granule cell layer obtained $4 \mathrm{~d}$ after ADX for the following morphological analyses of degenerating granule cells.

\section{Morphological analysis of apoptotic granule cells}

Nissl staining revealed a series of typical morphological changes during the course of the granule cell degeneration $4 \mathrm{~d}$ after ADX (Fig. 2). These different morphological profiles were considered to represent cell degeneration at presumed different stages (Kerr et al., 1972; Sloviter et al., 1993a,b). To describe these morphological changes simply, we divided different apoptotic profiles into four distinct types according to the results of studies on the process of apoptotic cell degeneration (Kerr et al., 1972; Sloviter et al., 1993a,b). The first type included the damaged granule cells that exhibited normal size for the nucleus and cell body while there were numerous darkly stained bodies within the nucleus (clumping of nuclear chromatin, Fig. 2A). Degenerating cells in the second type showed an extensive and tight condensation of nuclear materials and cytoplasm into a darkly stained small ball (pyknosis, Fig. 2B). The third type consisted of smaller degenerating cells with morphologic breaking up of the condensed nucleus and cytoplasm. Diverse morphological profiles were found at this type (disassembly of pyknotic cells, Fig. $2 C-E$ ). In the fourth type the condensed nucleus and cytoplasm were disassem- bled into many progressively smaller degenerating particles of debris (degenerating debris, Fig. $2 F$ ). In almost all of the Nisslstained hippocampal sections obtained $4 \mathrm{~d}$ after ADX, the different morphological profiles of apoptotic granule cells at these four types were observed clearly (Fig. 3). Semiquantitative analysis revealed that $\sim 68.1 \%$ of the apoptotic granule cells showed the morphological changes of the second and third types. Approximately $6.5 \%$ exhibited those of first type and $\sim 25.4 \%$ those of the fourth type. Similar numbers and morphological profiles of apoptotic granule cells were noted in the ADX rats 5-7 d after operation (data not shown). The morphology of the degenerating granule cells obtained $2 \mathrm{~d}$ after ADX mainly exhibited the patterns at the second and third types of cell degeneration. The degenerating debris was sparse within the granule cell layer.

\section{Effect of corticosterone replacement on ADX-induced hippocampal granule cell apoptosis}

Corticosterone replacement in drinking water $(30 \mu \mathrm{g} / \mathrm{ml})$ immediately after ADX prevented the appearance of silverimpregnated granule cells and Nissl-stained apoptotic granule cells in all of the ADX rats at each of the four time points examined. Our careful inspection of all of the sections from the rostral to posterior hippocampal granule cell layer in all of the rats failed to reveal any obvious apoptotic granule cells. The shamoperated rats, which received the same corticosterone treatment as the ADX rats, showed no obvious apoptotic granule cells in the hippocampus. Each ADX rat consumed, on average, 30-50 ml of corticosterone-containing water every day. Corticosterone treatment at this dose did not induce any abnormal behavior in the rats of either group. There was no significant difference in the BW between two groups at any time points. The BW (mean \pm SD) $4 \mathrm{~d}$ after operation was $\sim 120 \pm 5 \mathrm{gm}$ in the ADX rats and $\sim 125 \pm 5$ $\mathrm{gm}$ in the control rats. 

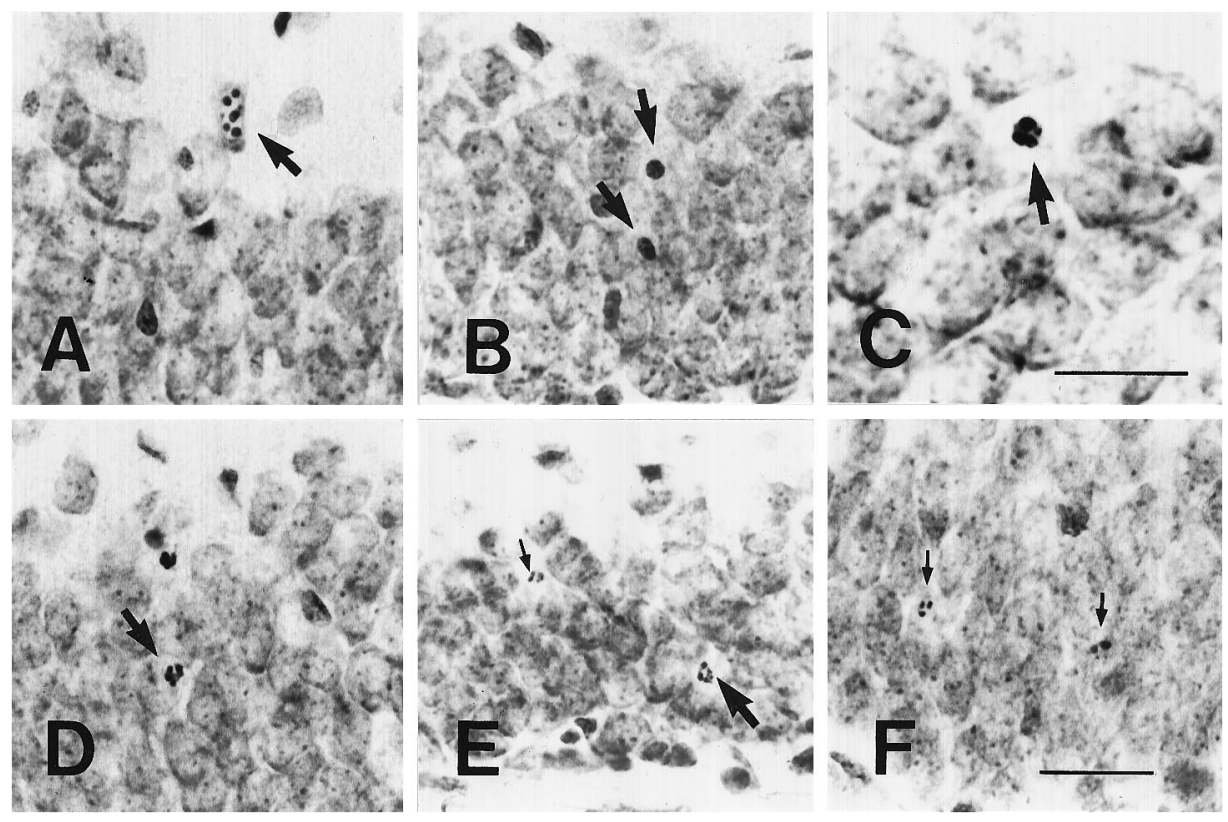

Figure 2. Nissl-stained sections show different morphological profiles of apoptotic granule cells $4 \mathrm{~d}$ after ADX. These apoptotic profiles are the clumping of chromatin within the nucleus of the normal-sized granule cell (the first type, arrow in $A$ ), condensation of the degenerating nucleus and cytoplasm into a darkly stained ball (the second type, arrows in $B$ ), gradual disassembly of the pyknotic granule cells into fragments (the third type, arrows from $C-E$ ), and the gradual disappearance of the degenerating debris (the fourth type, small arrows in $E, F$ ). Scale bars: in $C, 15 \mu \mathrm{m}$; in $F$, $50 \mu \mathrm{m}$ (applies to $A, B$, $D-F)$.

Table 1. The number of apoptotic granule cells with different morphological profiles at each time point after corticosterone replacement in the rats 4 d after ADX

\begin{tabular}{|c|c|c|c|c|c|}
\hline Group & $\begin{array}{l}\text { Clumping of } \\
\text { chromatin }\end{array}$ & $\begin{array}{l}\text { Pyknosis of } \\
\text { apoptotic cells }\end{array}$ & $\begin{array}{l}\text { Disassembly of } \\
\text { pyknotic cells }\end{array}$ & $\begin{array}{l}\text { Apoptotic } \\
\text { debris }\end{array}$ & $\begin{array}{l}\text { The total number } \\
\text { of dying cells }\end{array}$ \\
\hline $\mathrm{ADX}$ & $3.8 \pm 1.3$ & $18.6 \pm 4.9$ & $19.7 \pm 5.1$ & $14.2 \pm 4.6$ & $56.3 \pm 14.8$ \\
\hline $1 \mathrm{hr}$ & $2.9 \pm 1.1$ & $17.8 \pm 5.2$ & $18.6 \pm 5.7$ & $12.8 \pm 3.5$ & $52.2 \pm 15.1$ \\
\hline $4 \mathrm{hr}$ & $2.3 \pm 1.4$ & $18.1 \pm 4.6$ & $17.2 \pm 4.1$ & $13.6 \pm 3.8$ & $51.1 \pm 14.7$ \\
\hline $12 \mathrm{hr}$ & - & $17.8 \pm 4.7$ & $14.5 \pm 3.4$ & $11.8 \pm 3.5$ & $44.2 \pm 12.6$ \\
\hline $24 \mathrm{hr}$ & - & $8.2 \pm 3.4^{*}$ & $13.1 \pm 4.8$ & $9.3 \pm 2.7$ & $30.6 \pm 11.2^{*}$ \\
\hline $48 \mathrm{hr}$ & - & - & $4.9 \pm 2.5^{*}$ & $4.7 \pm 3.3^{*}$ & $9.7 \pm 4.6^{*}$ \\
\hline $72 \mathrm{hr}$ & - & - & - & - & - \\
\hline
\end{tabular}

Values correspond to means \pm SD per section. (-) denotes absent, and asterisks indicate levels of significance with respect to ADX rats $(p<0.05)$.

\section{The time course of lysis of apoptotic granule cells induced by ADX}

After the start of corticosterone replacement in the rats $4 \mathrm{~d}$ after ADX, individual apoptotic granule cells did not disappear for several hours. Tracing of the distribution of degenerating granule cells throughout the hippocampus by silver impregnation staining revealed apoptotic granule cells up to $48 \mathrm{hr}$ after the start of corticosterone treatment (Fig. 4). At 72 hr no silver-impregnated granule cells could be found at any portion of the hippocampus. The decrease in the number of silver-impregnated cells proceeded from the inner to the outer portion of the granule cell layer. Nissl staining revealed obvious sequential changes in the morphological profiles of degenerating granule cells at different time points (Fig. 5). At 1 and $4 \mathrm{hr}$ after corticosterone treatment, the morphological characteristics of degenerating granule cells (Fig. $5 A, B$ ) exhibited no marked difference from those in $\mathrm{ADX}$ rats without corticosterone treatment (shown in Fig. 3). Twelve hours after the start of corticosterone replacement, no granule cells at the first type (clumping of the chromatin within the nucleus; Fig. $5 C$ ) were identified. The main morphological feature of degenerating gran- ule cells was pyknosis. Some degenerating debris and broken pyknotic cells were found (Fig. 5C). At $24 \mathrm{hr}$ many pyknotic cells began to break up. Tightly condensed degenerating cells were not the main morphological feature of degenerating granule cells (Fig. 5D). After corticosterone treatment for $48 \mathrm{hr}$, many pyknotic granule cells were broken up into very small pieces of degenerating debris (Fig. 5E). Chromatin condensation with the nucleus and tightly condensed pyknotic cells were not observed at this time. The disappearance of apoptotic granule cells usually took place first at the inner portion of the granule cell layer. Seventytwo hours later, all of the apoptotic granule cells and degenerating debris had disappeared. The results of semiquantitative analysis (in Table 1) showed the changes in the number of apoptotic granule cells with diverse morphological profiles at different time points after corticosterone replacement in the rats $4 \mathrm{~d}$ after ADX. As the survival time increased, the apoptotic granule cells gradually disappeared (from the clumping of nuclear chromatin to the degenerating debris) within $72 \mathrm{hr}$. None of the $30 \mathrm{ADX}$ and 12 sham-operated rats that received corticosterone replacement displayed any abnormal behavior changes. The BW in the ADX rat 

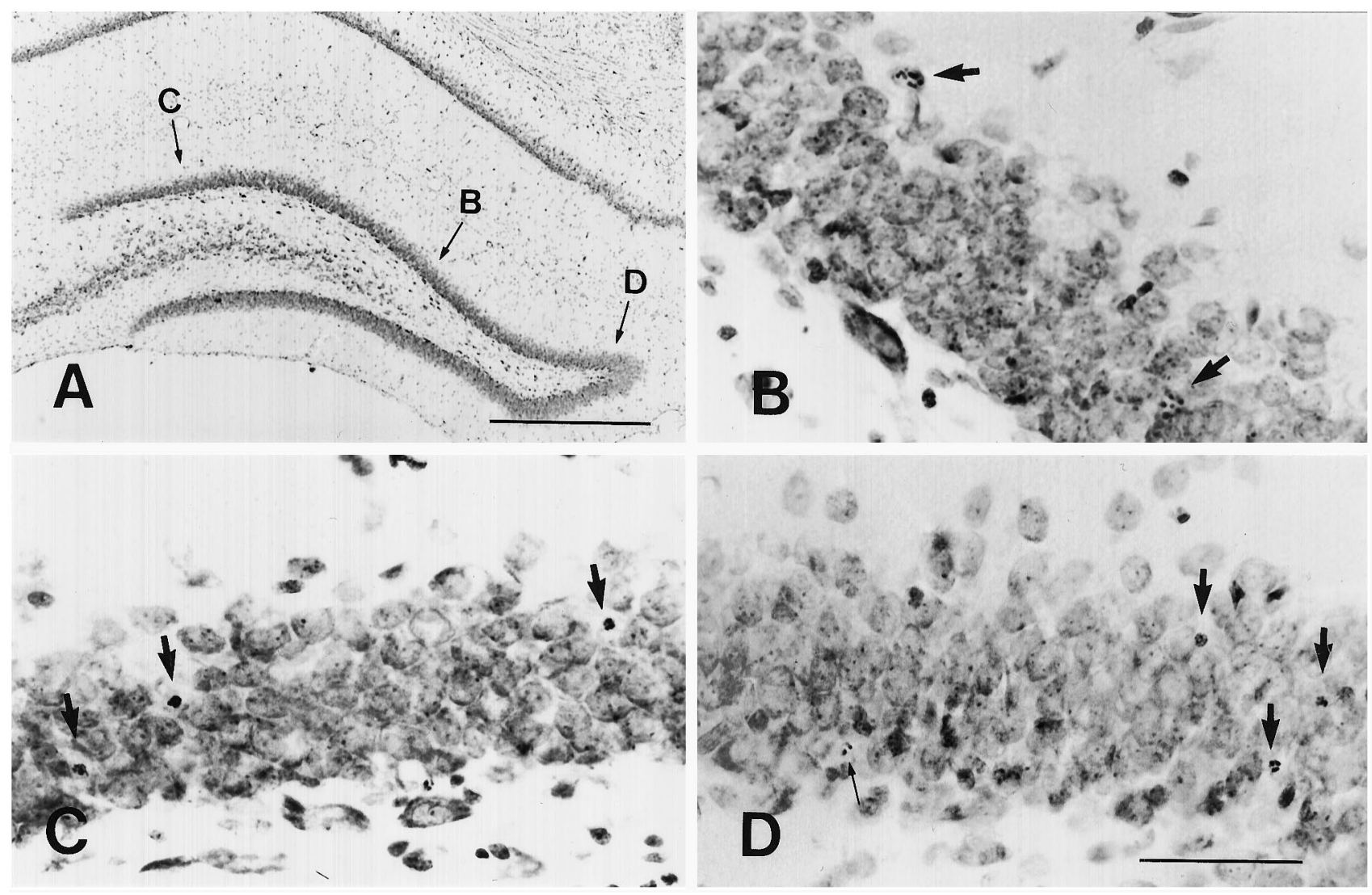

Figure 3. Apoptotic cells with different morphological profiles $4 \mathrm{~d}$ after ADX are present within the granule cell layer at the same section. $B-D$ are higher magnification views of the same sites labeled by small capital letters $B, C$, and $D$ in $A$. The apoptotic cells at the first (arrows in $B$ ), second and third (arrows in $C, D$ ), and fourth types (small arrow in $D$ ) are distributed in the same section. Most apoptotic granule cells exhibited the morphological profiles at the second and third types. Scale bars: in $A, 200 \mu \mathrm{m}$; in $D, 70 \mu \mathrm{m}$ (for $B-D$ ).

group did not exhibit any significant difference from that in the control group at any of six time points. Fewer than one or two apoptotic granule cells per Nissl-stained section were found in the hippocampal dentate gyrus of the sham-operated rats at each of six time points.

\section{The change of GR-IR after corticosterone treatment}

In our previous investigation (Visser et al., 1996) and the present study we noted that the GR-IR always disappeared within the hippocampal granule cell layer or other brain areas after complete ADX, which induced numerous hippocampal apoptotic granule cells. The absence of GR-IR exhibited no relationship with the number of apoptotic granule cells. To elucidate whether corticosterone replacement in ADX rats exerts its effects promptly on the granule cells (Becker et al., 1986; Mendall et al., 1986), we examined the GR-IR within the hippocampus after injection of corticosterone. The GR-IR in the hippocampus, including the dentate gyrus, quickly reappeared $1 \mathrm{hr}$ after corticosterone injection in all of the ADX rats (Fig. 6). The strong GR-IR was distributed consistently throughout the whole brain (including the granule cell layer) from $1 \mathrm{hr}$ after corticosterone replacement until $72 \mathrm{hr}$ later. There was no obvious difference in the GR-IR between corticosterone-treated ADX rats and sham-operated rats at any time points. In our other experiments (data not shown), the reappearance of GR-IR in ADX rat hippocampus could be observed successively several months after treatment of ADX rats with corticosterone.

\section{DISCUSSION}

\section{The time course of lysis of apoptotic granule cells in adult rat dentate gyrus after ADX}

It is very difficult to determine directly the time course for elimination of apoptotic cells from the early to late stage of cell degeneration in vivo, because apoptosis proceeds continuously in individual cells within the same organ at different times (Kerr et al., 1972). Once the tissues are cut, only one time point is shown, which presents difficulty, particularly in the brain. Kerr et al. (1972) hypothesized that the process of lysis of apoptotic cells is completed fairly rapidly: apoptotic bodies may form and disappear within several hours. However, they did not provide direct morphological evidence to support their hypothesis. Although an in vitro experiment with blood T-cells and time-lapse microcinematography revealed that the process of the disappearance of degenerating cells was completed within a few hours (Sanderson, 1976), this time course is probably different from that found in in vivo. Actually, no direct morphological evidence has ever been presented to demonstrate the time course of lysis of apoptotic cells within the adult brain in vivo (Russell et al., 1972; Sanderson, 1976; Matter, 1979; Wyllie et al., 1980; Kerr et al., 1987; Busch et al., 1990). In this study we discovered that the entire process of lysis of apoptotic granule cells from the beginning to the end required $\sim 72 \mathrm{hr}$. This result is different from the concept that the apoptotic cell appearance persists for only a matter of several hours in living tissue (Russell et al., 1972; Kerr et al., 1987; 


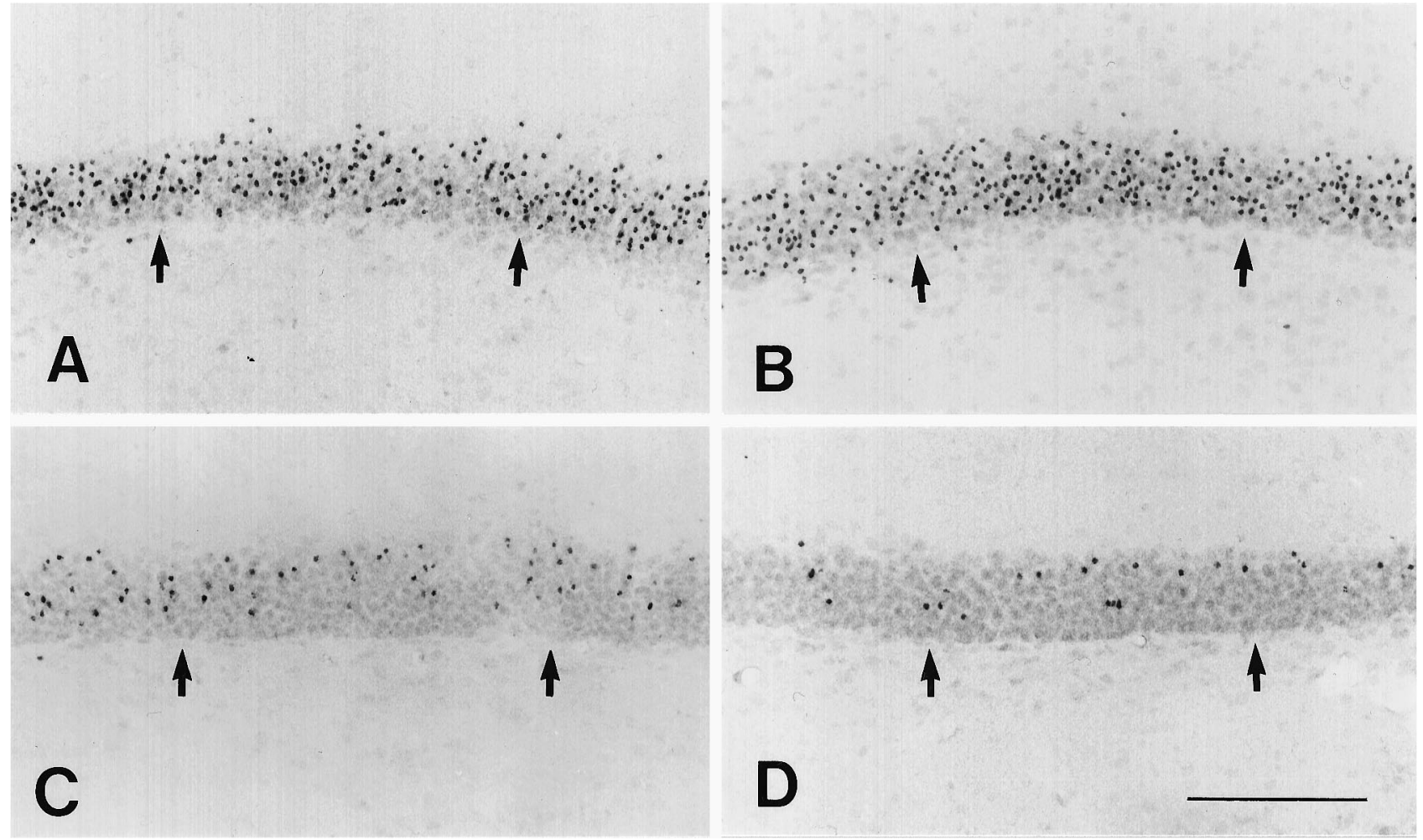

Figure 4. Photomicrographs illustrate the silver-stained granule cells (arrows) after corticosterone replacement in rats $4 \mathrm{~d}$ after ADX. $A-D$ show the silver-impregnated cells within the granule cell layer at 1, 12, 24, and $48 \mathrm{hr}$ after corticosterone treatment, respectively. The disappearance of silver-impregnated granule cells was obvious in the inner portion of the granule cell layer. Scale bar, $150 \mu \mathrm{m}$.

Gavrieli et al., 1992). Our results may reflect the time course for the removal of ADX-induced apoptotic granule cells from the in vivo hippocampus.

Our study demonstrated that loss of corticosterone definitely resulted in hippocampal granule cell degeneration in all of the ADX rats and that $\mathrm{ADX}$-induced granule cell apoptosis was blocked completely by the treatment with corticosterone in drinking water immediately after ADX (Sloviter et al., 1989, 1993a; Gould et al., 1990). These results suggested that corticosterone replacement in this study could protect granule cells continuously against ADX-induced apoptosis. An important hypothesis in this study was that injection of 1.5 $\mathrm{mg}$ of corticosterone would rescue the uninjured but hormonedeficient granule cells promptly from ADX-induced apoptosis. This hypothesis was supported by several sets of evidence. (1) Our monitoring of the volume of corticosterone consumed by each ADX rat daily revealed that it ranged from 0.9 to $1.5 \mathrm{mg}$. The ADX rats receiving corticosterone replacement at this volume daily did not show any apoptotic granule cells, suggesting that corticosterone (1.5 mg injection plus subsequent replacement in drinking water) would be distributed quickly to all of the hormone-deficient cells and would be enough to block granule cell apoptosis (Gould et al., 1990). (2) The clumping of chromatin within the nucleus of apoptotic granule cells, the morphological profile that was considered as representing the early stage of cell degeneration (Kerr et al., 1972; Gould et al., 1990; Sloviter et al., 1993a,b), was not found throughout the hippocampus at $12 \mathrm{hr}$ after the start of corticosterone treatment, indicating that corticosterone did rescue the viable granule cells promptly from hormone-deficient apoptosis. (3) Previous studies revealed that complete ADX induced the disappearance of the immunoreactivity of GR type II corticosteroid receptors (Reul et al., 1987; Kawata, 1995) within the rat hippocampus (Visser et al., 1996). Whether
GR-IR cells exist in the brain is a good indicator of whether corticosterone is present within the rat body. Therefore, the reappearance of normal GR-IR after ADX could be considered as the evidence that glucocorticoids exert an effect on cells (Becker et al., 1986; Mendall et al., 1986). In this study we found that the GR-IR in the $\mathrm{ADX}$ rat granule cells normally reappeared $1 \mathrm{hr}$ after corticosterone replacement, suggesting that corticosterone rapidly exerted an effect on the granule cells. Last, although all of the control rats received corticosterone replacement at the same dose daily, none of them exhibited apoptosis granule cells within the dentate gyrus at any time points, implying that corticosterone replacement did not result in granule cell apoptosis. Conversely, although we supplied the ADX rats with adequate corticosterone to block the apoptosis of healthy but hormone-deficient granule cells, there were still apoptotic granule cells in the dentate gyrus up to $48 \mathrm{hr}$ after the start of corticosterone replacement, validating our second hypothesis that corticosterone replacement would not protect the already damaged granule cells from irreversible hormone-deficient apoptosis (Kerr et al., 1972). Therefore, the granule cells already injured would continue to undergo apoptosis after corticosterone replacement. Four days after $\mathrm{ADX}$, apoptotic granule cells with different apoptotic profiles were identified clearly within the same hippocampal section. These morphological profiles might represent the different stages of apoptosis in the process of cell degeneration (Kerr et al., 1972, 1987; Sanderson, 1976; Wyllie et al., 1980; Busch et al., 1990; Sloviter et al., 1993a,b). Thus, at the time when the ADX rats received corticosterone injection, apoptotic granule cells at different stages of cell degeneration were already present. Sequentially, the apoptotic cells at the latest stage of the degeneration process disappear earliest (Sanderson, 1976). Conversely, the apoptotic granule cells at the earliest stage will disappear latest. 


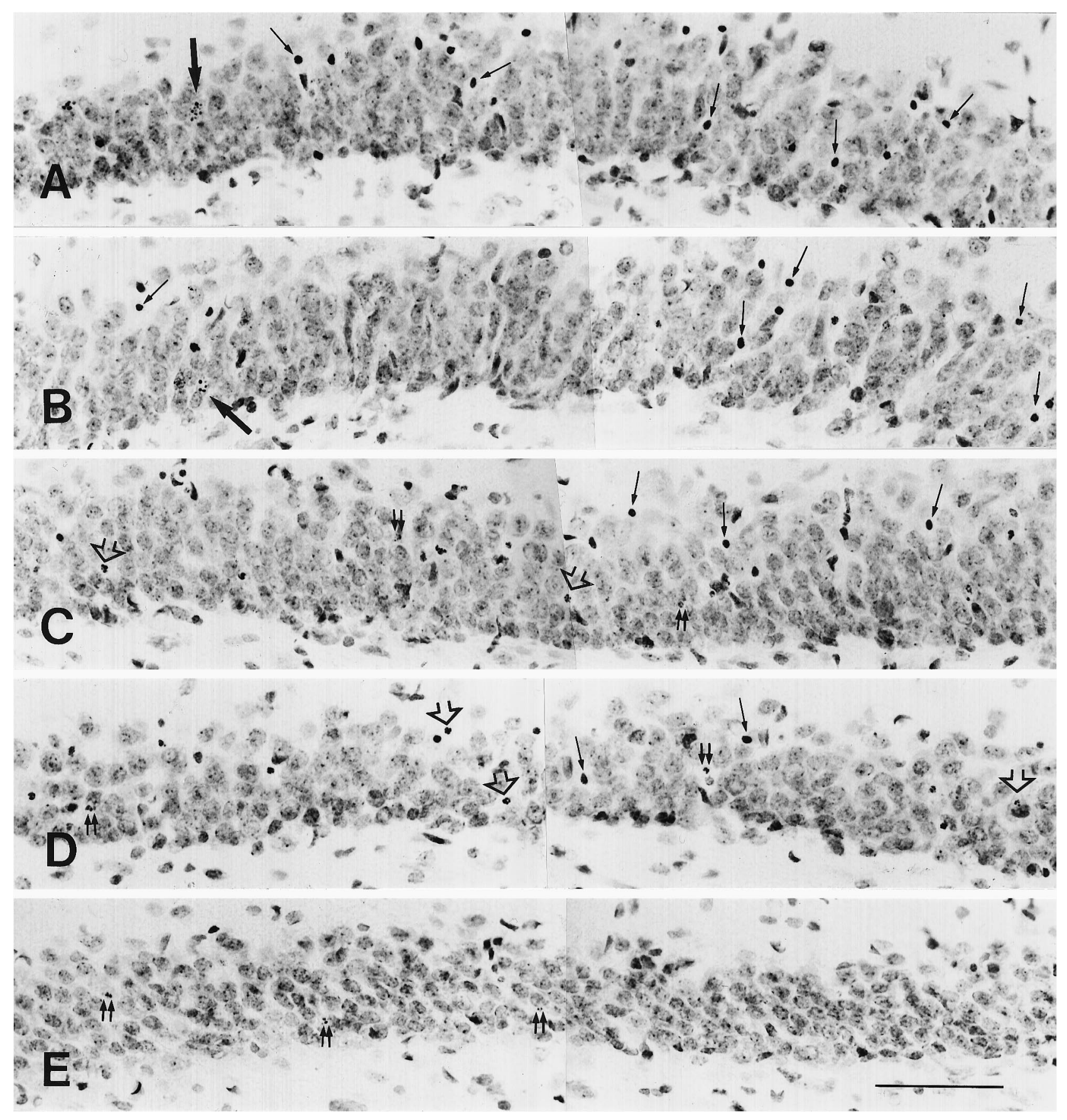

Figure 5. Nissl-stained sections show the morphological changes of the apoptotic granule cells at different times after corticosterone replacement in the rats $4 \mathrm{~d}$ after ADX. At $1(A)$ and $4 \mathrm{hr}(B)$ after corticosterone replacement, different morphological profiles of apoptotic cells were identified. Large and medium-sized arrows in $A$ and $B$ indicate the clumping of chromatin within the nucleus and pyknosis of apoptotic cells, respectively. The main morphological profile of apoptotic cells at $12 \mathrm{hr}$ was pyknosis of degenerating cells (medium-sized arrows in $C$ ) and disassembly of pyknotic cells (open arrows in C). Double small arrows indicate the degenerating debris. At $24 \mathrm{hr}$ later, the breaking up of pyknotic cells into fragments became the main morphological feature (open arrows in $D$ ). At $48 \mathrm{hr}$, degenerating debris with different sizes (double small arrows in $E$ ) still were observed. The apoptotic cells with clumping of chromatin within the nucleus disappeared from the granule cell layer at 12, 24, and $48 \mathrm{hr}$ after corticosterone replacement. Scale bar, $80 \mu \mathrm{m}$.

On the basis of above analyses, we conclude that corticosterone injection into the ADX rats quickly protected the healthy granule cells from hormone-deficient apoptosis, whereas the already damaged granule cells underwent further degeneration. The ADXinduced apoptotic granule cells do not all disappear at the same time because various apoptotic cells at different stages coexist within the hippocampus. The apoptotic cells at the earliest stage of cell degeneration immediately after the start of corticosterone injection disappeared latest. Therefore, the duration from the corticosterone injection until the time when the last degenerating debris disappeared approximately represents the time course of the elimination of apoptotic granule cells in the in vivo brain.

Throughout our experiments corticosterone replacement did not induce any obvious cell death in any field of the hippocampus 

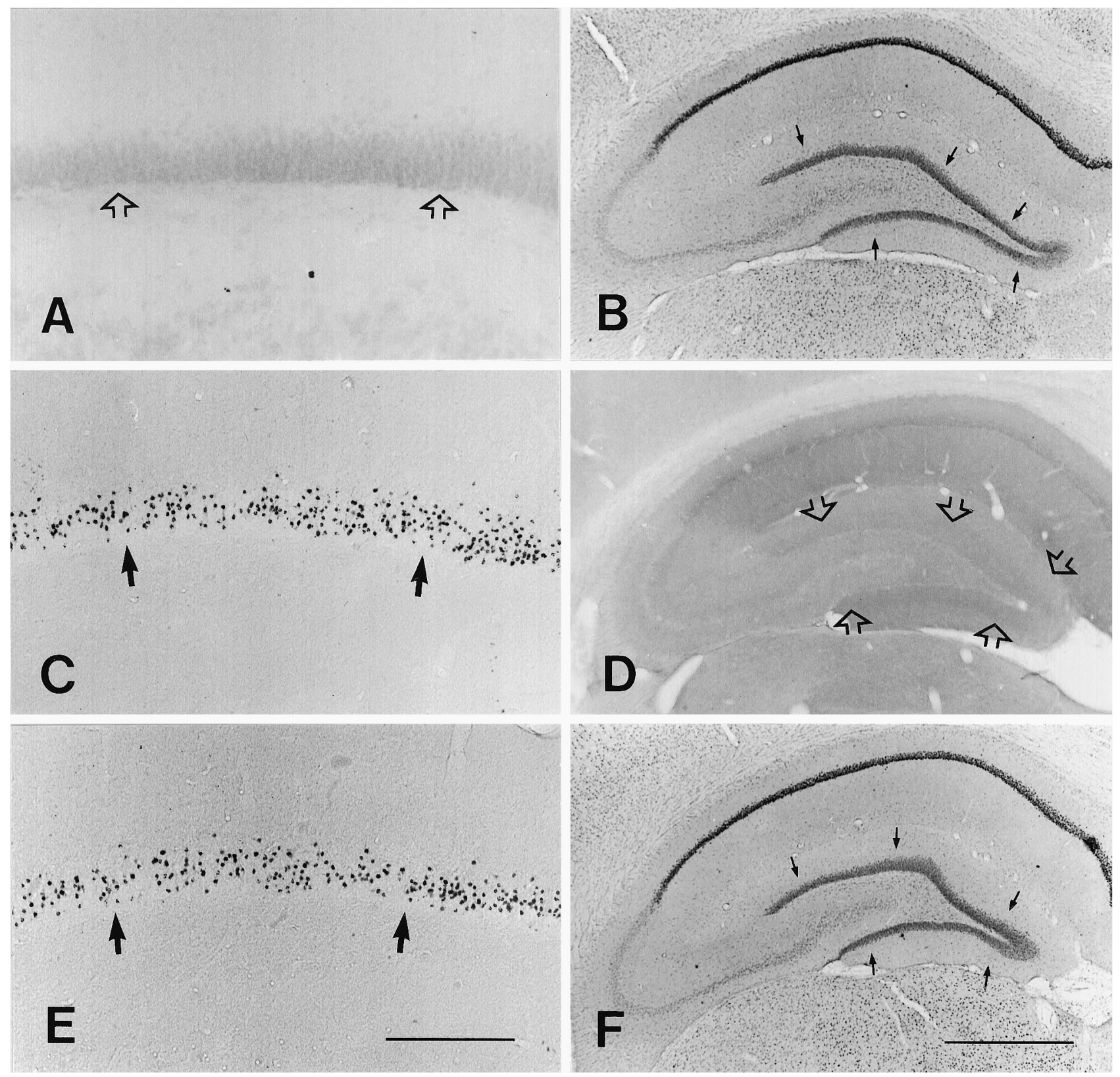

Figure 6. Photomicrographs illustrating silver-stained granule cells and GR-IR within the hippocampus. In the sham-operated rat no silver-stained granule cells were seen (open arrows in $A$ ), and the normal GR-IR is present within the granule cell layer (arrows in $B$ ). At $4 \mathrm{~d}$ post-ADX, numerous silver-stained cells (arrows in $C$ ) and the complete disappearance of GR-IR were present in the hippocampus (open arrows in $D$ indicate the granule cell layer). The reappearance of normal GR-IR in the granule cell layer (arrows in $F$ ) was identified clearly $1 \mathrm{hr}$ after corticosterone replacement, although many silver-stained cells (arrows in $E$ ) still were distributed within the suprapyramidal blade of the granule cell layer. Scale bars: in $E, 200 \mu \mathrm{m}$ (for $A$, $C$, $E$ ); in $F, 250 \mu \mathrm{m}$ (for $B, D, F)$.

in either the ADX or control rats, and the BW of the control and experimental groups that received corticosterone treatment did not decrease at any time points. These results excluded the possibility that corticosterone replacement in our experiment exerted possible neurotoxic or stress effects on the hippocampal neurons (Sapolsky, 1985, 1986), although the dose of corticosterone used was $5-10 \mu \mathrm{g} / \mathrm{ml}$ higher than that used in previous studies (Sloviter et al., 1989, 1993a; Gould et al., 1990). However, we should emphasize that this time course is based on a conservative estimate, because the disappearance of apoptotic debris as assessed by light microscopy may not coincide with that which would have been observed under electron microscope. The apoptotic bodies that can be detected with light microscope are thought to comprise only a small fraction of the total number of cell remnants present (Kerr et al., 1972). Thus, the time course of the granule cell degeneration would be slightly longer than the time course that we observed. Further electron microscopic analysis is now in progress.

\section{Possibility of corticosterone regulating the time course of granule cell degeneration}

At present, we do not know whether corticosterone treatment extends the time course of lysis of apoptotic cells. It has been reported that $\sim 50 \%$ of pyknotic granule cells in the dentate gyrus 
of postnatal rats contain GR (Gould et al., 1992). Corticosterone might regulate the apoptotic granule cells at the early stage of the degeneration process. The time course of the elimination of apoptotic granule cells might change after the alteration of the circulating corticosterone level. Therefore, our results reflect only the time course of the lysis of apoptotic granule cells in the presence of corticosterone. Experiments furthering our understanding of whether glucocorticoids change the process of apoptosis are needed.

\section{Potential significance of these findings}

Our findings are of interest to other researchers studying the regulation of apoptosis and analyzing the morphological changes of apoptotic cells. With this simple method the time course for clearing apoptotic cells in other apoptotic models could be determined (for example, the apoptotic cell death within the adrenal cortex after ACTH withdrawal, the apoptotic prostate cells after castration, and so on). With this approach the detailed course for removing apoptotic cells could be clarified, particularly the changes in the morphological profiles of the apoptotic cells. Furthermore, many neurotrophic factors and proteins have the potential to induce or prevent cell death (Buttyan et al., 1989; Fanidi et al., 1992; Garcia et al., 1992; Komuro and Rakic, 1993; Louis et al., 1993). However, none has attempted to demonstrate whether these factors influence the process of cell death in vivo. Treatment of ADX rats receiving corticosterone replacement with other neurotrophic factors or regulators, followed by observation of the change in the lysis of apoptotic granule cells, could supply direct morphological evidence pertaining to the effects of these factors on the process of apoptosis in the CNS.

\section{REFERENCES}

Becker PB, Gloss B, Schmid W, Strahle U, Schutz G (1986) In vivo protein-DNA interactions in glucocorticoid response element require the presence of the hormone. Nature 324:686-688.

Busch W, Kleine L, Tenniswood M (1990) The biochemistry of cell death by apoptosis. Biochem Cell Biol 88:1071-1074.

Buttyan R, Olsson CA, Pintar J, Chang C, Bandyx M, Sawczuk IS (1989) Induction of TRPM-2 gene in cells undergoing programmed cell death. Mol Cell Biol 9:3473-3481.

Clarke PGH (1990) Developmental cell death: morphological diversity and multiple mechanism. Anat Embryol (Berl) 181:195-209.

Fanidi A, Harrington EA, Even GI (1992) Cooperative interaction between c-myc and Bcl-2 proto-oncogenes. Nature 359:554-556.

Gallyas F, Wolff JR, Bottcher H, Zaborsky L (1980) A reliable and sensitive method to localize terminal degeneration and lysosomes in the central nervous system. Stain Technol 55:299-306.

Garcia I, Martinou I, Tsujimoto Y, Martinous JC (1992) Prevention of programmed cell death of sympathetic neurons by the Bcl-2 protooncogene. Science 258:302-304.

Gavrieli Y, Sherman Y, Ben-Sasson A (1992) Identification of programmed cell death in situ via specific labeling of nuclear DNA fragmentation. J Cell Biol 119:439-501.

Gould E, Woolley CS, McEwen BS (1990) Short-term glucocorticoid manipulations affect neuronal morphology and survival in the adult dentate gyrus. Neuroscience 37:367-375.

Gould E, Woolley CS, Cameron HA, Daniels DC, McEwen BS (1992) Expression of adrenal steroid receptors by newly born cells and pyknotic cells in the dentate gyrus of the postnatal rat. Mol Cell Neurosc $3: 44-48$.
Jaarsma D, Postema F, Korf J (1992) Time course and distribution of neuronal degeneration in the dentate gyrus of rat after adrenalectomy: a silver impregnation study. Hippocampus 2:143-150.

Kawata M (1995) Roles of steroid hormones and their receptors in structural organization in the central nervous system. Neurosci Res 24:1-46.

Kerr JFR, Wyllie AH, Currie AR (1972) Apoptosis: basic biological phenomenon with wide-ranging implication in tissue kinetics. $\mathrm{Br} \mathbf{J}$ Cancer 26:239-257.

Kerr JFR, Searle J, Harmon BV, Bisshop CJ (1987) Apoptosis. In: Perspective on mammalian cell death (Potten CS, ed), pp 93-128. Oxford: Oxford UP.

Komuro H, Rakic P (1993) Modulation of neuronal migration by NMDA receptors. Science 260:95-97.

Louis JC, Magal E, Takayama S, Varon S (1993) CNTF protection of oligodendrocytes against neural and tumor necrosis factor-induced death. Science 259:689-692.

Matter A (1979) Microcinematographic and electron microscopic analysis of target cell lysis induced by cytotoxic T lymphocytes. Immunology 36:179-190.

Mendall DB, Bodwell JE, Munck A (1986) Glucocorticoid receptors lacking hormone-binding activity are bound in nuclei of ATP-depleted cells. Nature 324:478-480.

Morimoto M, Morita N, Kawata M (1996) Distribution of mRNA and protein of glucocorticoid receptor in rat central nervous system. Neurosci Res 26:235-269.

Reul JMHM, van den Bosch FR, de Kloet ER (1987) Relative occupation of type-I and type-II corticosteroid receptors in rat brain following stress and dexamethasone treatment: functional implication. J Endocrinol 115:459-467.

Russell SW, Rosenau W, Lee JC (1972) Cytolysis induced by human lymphotoxin. Am J Pathol 69:103-118.

Sanderson CJ (1976) The mechanism of T cell-mediated cytotoxicity. II. Morphological study of cell death by time lapse microcinematography. Proc R Soc Lond [Biol] 192:241-255.

Sapolsky R (1985) A mechanism for glucocorticoid toxicity in the hippocampus: increased vulnerability of neurons to metabolic insults. J Neurosci 5:1228-1232.

Sapolsky R (1986) Glucocorticoids toxicity in the hippocampus: temporal aspects of synergy with kainic acid. Neuroendocrinology 43:440-444.

Sapolsky RM, Stein-Behrens BA, Armanini MP (1991) Long-term adrenalectomy causes loss of dentate gyrus and pyramidal neurons in the adult hippocampus. Exp Neurol 114:246-249.

Sloviter RS, Valiquette G, Abrams GM, Ronk EC, Sollas AL, Paul LA, Neubort S (1989) Selective loss of hippocampal granule cells in the mature rat brain after adrenalectomy. Science 243:535-538.

Sloviter RS, Sollas AL, Dean S, Neubort S (1993a) Adrenalectomyinduced granule cell degeneration in the rat hippocampal dentate gyrus: characterization of an in vivo model of controlled neuronal death. J Comp Neurol 330:324-336.

Sloviter RS, Dean E, Neubort S (1993b) Electron microscopic analysis of adrenalectomy-induced hippocampal granule cell degeneration in the rat: apoptosis in the adult central nervous system. J Comp Neurol 330:337-351.

Ucker PS (1991) Death by suicide: one way to go in mammalian cellular development? New Biol 3:103-109.

Vaux DL (1993) Toward an understanding of the molecular mechanism of physiological cell death. Proc Natl Acad Sci USA 90:786-789.

Visser DTM, Hu Z, Morimoto M, Kawata M (1996) The alteration of glucocorticoid receptor immunoreactivity in the rat forebrain following short-term and long-term adrenalectomy. Brain Res 729:216-222.

Wyllie AH (1981) Glucocorticoid-induced thymocytes apoptosis is associated with endogenous endonuclease activation. Nature 284:555-556.

Wyllie AH, Kerr JFR, Currie AR (1980) Cell death: the significance of apoptosis. Int Rev Cytol 68:251-306. 